\title{
Experimental intra-ovum infection of salmonid eggs with Renibacterium salmoninarum and vertical transmission of the pathogen with such eggs despite their treatment with erythromycin
}

\author{
T. P. T. Evelyn, L. Prosperi-Porta \& J. E. Ketcheson \\ Department of Fisheries and Oceans, Fisheries Research Branch, Pacific Biological Station, Nanaimo, British Columbia \\ V9R 5K6, Canada
}

\begin{abstract}
Studies with eggs of steelhead trout Salmo gairdneri (Richardson) and coho salmon Oncorhynchus kisutch (Walbaum) showed that the eggs can be infected internally with Renibacterium salmoninarum by immersing them prior to fertilization and water-hardening in coelomic fluid containing high numbers of $R$. salmoninarum cells. These results support our hypothesis that, in vivo, salmonid eggs acquire their intra-ovum $R$. salmoninarum infections from heavily infected coelomic fluid that surrounds them in 'culprit' fish following their release to the body cavity. Whether eggs are also infected early in oogenesis is still not known. Intra-ovum infection rates obtained were low ( 3.5 to $5.0 \%$ and did not increase if eggs were fertilized while still immersed in the infected coelomic fluid. These and other data discussed in the paper lead to the conclusion that the male salmonid plays a relatively unimportant role in the vertical transmission of $R$. salmoninarum. Water-hardening of experimentally infected coho salmon eggs in erythromycin did not appear to affect the intra-ovum infection rate, and fry hatching from the treated eggs carried the pathogen.
\end{abstract}

\section{INTRODUCTION}

Earlier studies (Evelyn et al. 1984a, b, Evelyn et al. 1986 b) reported that fish with coelomic fluid containing large numbers of cells of the kidney disease bacterium Renibacterium salmoninarum invariably yielded eggs that were infected internally with the pathogen. Intra-ovum infection rates for eggs obtained from such fish ranged from about 5 to $15 \%$. These findings led us to speculate that salmonid eggs acquire their $R$. salmoninarum infections passively, via the micropyle, from infected coelomic fluid. This fluid is in intimate contact with the eggs once they have been released to the body cavity following ovulation. That coelomic fluid might be the source of infection for salmonid eggs was further supported by observations on one coho salmon in which, despite particularly heavy infection, the coelomic fluid was free of $R$. salmoninarum: eggs from this fish proved to be free of the pathogen.

In this paper, we report experiments proving that salmonid eggs may indeed acquire their intra-ovum
Renibacterium salmoninarum infections from infected coelomic fluid and that eggs so infected are capable of transmitting the infection to resulting fry even when treated with erythromycin in an attempt to prevent the transfer. The experiments also provided us with the opportunity to assess the role of the male salmonid in the vertical transmission of $R$. salmoninarum.

\section{MATERIALS AND METHODS}

In the experiments outlined below we investigated whether it was possible to infect eggs of steelhead trout Salmo gairdneri (Richardson) and coho salmon Oncorhynchus kisutch (Walbaum) by immersing them in coelomic fluid deliberately contaminated with Renibacterium salmoninarum. In one trial (with coho salmon eggs), the contaminating dose exceeded by 100 -fold the highest infection level seen under natural conditions. We also investigated whether the infection rate in steelhead trout and coho salmon eggs could be increased by fertilizing the eggs while they were 
immersed in the $R$. salmoninarum-contaminated fluid. Finally, using coho salmon eggs, we investigated whether water-hardening of the eggs in various forms of erythromycin eliminated experimentally induced intra-ovum $R$. salmoninarum infections and whether fry resulting from experimentally infected eggs carried the pathogen. The details follow.

Eggs and milt. The steelhead trout and coho salmon that served as the source of eggs and milt were adult fish that had returned from the sea to spawn at the Department of Fisheries and Oceans (DFO) salmonid enhancement facility at Big Qualicum River, Vancouver Island, British Columbia (B. C.), Canada. The fish were grossly normal externally and internally, and tests (Gram and fluorescent antibody stains; culture) performed on samples of kidncy, coclomic fluid, and milt failed to detect Renibacterium salmoninarum. Eggs and milt were transported to the laboratory separately in ciean, covered, iced, plastic containers. In the laboratory, eggs and milt were stored at 0 to $4^{\circ} \mathrm{C}$ until needed, care being taken to ensure that they were not deprived of oxygen. Prior to storage, eggs were drained free of coelomic fluid. The latter was collected, freed of particulate material by centrifugation (2000 $x$ $\mathrm{g}$ for $20 \mathrm{~min}$ at $4^{\circ} \mathrm{C}$ ), and deliberately contaminated with $R$. salmoninarum (see below). The contaminated coelomic fluid served as the milieu in which the intraovum infections were to be attempted (see later).

Bacteria. Isolate \#384 of Renibacterium salmoninarum was used to infect the eggs in this study.
The isolate was obtained from a moribund juvenile chinook salmon Oncorhynchus tshawytscha (Walbaum) at the DFO Quinsam River Hatchery, Vancouver Island, B. C. The fish was one of a number severely affected with bacterial kidney disease (BKD). The isolate (its first subculture) had been stored at $-90^{\circ} \mathrm{C}$ in the broth form of KDM2 (Evelyn 1977) until used. For use, the culture was grown on $\mathrm{KDM} 2$ for $14 \mathrm{~d}$ at $15^{\circ} \mathrm{C}$. Resulting growth was aseptically scraped off the medium and suspended in cold sterile peptone $(0.1 \%)$-saline $(0.85 \%)$ to a calculated turbidity of 20.0 $\mathrm{OD}$ at $420 \mathrm{~nm}$ (equivalent to ca $1.5 \times 10^{10} \mathrm{R}$. salmoninarum cells $\mathrm{ml}^{-1}$ ). A sufficient volume of the suspension, or appropriately diluted suspension, was centrifuged, as already described, to produce a cell pellet. The latter was resuspended in clarified coelumic fluid to provide the $R$. salmoninarum counts indicated in Table 1. Uniform dispersion of $R$. salmoninarum cells in the suspensions was achieved by repeatedly passing the suspensions through a 26 gauge needle.

Antimicrobial agents. Several forms of erythromycin, an antibiotic known to be active against Renibacterium salmoninarum, were tested for their ability to free experimentally infected coho salmon eggs of intra-ovum $R$. salmoninarum: these included erythromycin phosphate (supplied as Gallimycin ${ }^{\circledR}$ by A. P. A. Inc, Calgary, Alberta, Canada); and erythromycin ethylsuccinate, erythromycin stearate, and erythromycin base (supplied in purified form by Sigma Chemical Co. Ltd., St. Louis, Missouri, USA). External disinfec-

Table 1. Summary of the sequence of manipulations and assays performed on steelhead trout and coho salmon eggs, and on fry hatching from coho salmon eggs, during egg infection trials with Renibacterium salmoninarum (Rs)

\begin{tabular}{|c|c|c|c|c|c|c|}
\hline \multirow[t]{2}{*}{ Egg source } & \multicolumn{6}{|c|}{ Treatment or assay } \\
\hline & $\begin{array}{l}\text { Eggs immersed } \\
\text { in coelomic } \\
\text { fluid with } \\
\text { indicated no. Rs } \\
\text { cells } \mathrm{ml}^{-1}\end{array}$ & $\begin{array}{l}\text { Eggs } \\
\text { insemi- } \\
\text { nated }\end{array}$ & $\begin{array}{l}\text { Eggs hardened } \\
\text { in water or } \\
\text { in aqueous } \\
\text { erythromycin }\end{array}$ & $\begin{array}{l}\text { Eggs surface- } \\
\text { disinfected with } \\
\text { iodine and } \\
\text { rinsed with } \\
\text { sterile water }\end{array}$ & $\begin{array}{l}\text { Eggs } \\
\text { assayed for } \\
\text { intra-ovum } \\
\quad \text { Rs }\end{array}$ & $\begin{array}{l}\text { Resulting } \\
\text { fry assayed } \\
\text { for Rs }\end{array}$ \\
\hline \multirow[t]{5}{*}{ Steelhead trout } & 0 & No & Water & Yes & Yes & - \\
\hline & 0 & Yes & Water & Yes & Yes & No \\
\hline & $1.4 \times 10^{3}$ & Yes & Water & Yes & Yes & No \\
\hline & $1.4 \times 10^{9}$ & No & Water & Yes & Yes & - \\
\hline & $1.4 \times 10^{9}$ & Yes & Water & Yes & Yes & No \\
\hline \multirow[t]{6}{*}{ Coho salmon } & 0 & No & Water & Yes & Yes & - \\
\hline & 0 & Yes & Water & Yes & Yes & Yes \\
\hline & $1.3 \times 10^{6}$ & No & Water & Yes & Yes & - \\
\hline & $1.3 \times 10^{12}$ & No & Water & Yes & Yes & - \\
\hline & $1.3 \times 10^{12}$ & Yes & Water & Yes & Yes & Yes \\
\hline & $1.3 \times 10^{12}$ & Yes & Erythromycin & Yes & Yes $^{\circ}$ & Yes $^{\mathrm{D}}$ \\
\hline \multicolumn{7}{|c|}{$\begin{array}{l}\text { Although eggs were treated with } 4 \text { different forms of erythromycin, only } 1 \text { group, treated with erythromycin phosphate, was } \\
\text { assayed for intra-ovum Rs. Prior to the assay, this group was incubated in running water }\left(5^{\circ} \mathrm{C}\right) \text { for } 3 \mathrm{~d} \text { to permit a reasonable } \\
\text { opportunity for drug-pathogen contact } \\
\text { b These fry resulted from } 4 \text { lots of eggs, each of which was treated with a different form of erythromycin }\end{array}$} \\
\hline
\end{tabular}


tion of the eggs was accomplished using iodine in the form of povidone-iodine (supplied as Ovadine ${ }^{\circledR}$, Syndel Laboratories Ltd., Vancouver, B. C.).

Egg infection and handling protocols. Table 1 summarizes the sequence of manipulations and indicates the nature of the assays performed on eggs and resulting fry. Other relevant details follow. To infect the eggs, the soft, unfertilized eggs, drained free of coelomic fluid, were immersed in just enough clarified coelomic fluid (controls) or coelomic fluid contaminated with Renibacterium salmoninarum (2 dosage levels) to thoroughly wet all egg surfaces. The volume of coelomic fluid used simulated that found in the fish yielding the eggs: $1.3 \mathrm{ml}$ of fluid per 100 eggs in steelhead trout and $3.1 \mathrm{ml}$ of fluid per 100 eggs in coho salmon. The coelomic fluid-egg mixtures were then incubated for $24 \mathrm{~h}$ at $4{ }^{\circ} \mathrm{C}$ in sealed, sterile, plastic bags, each containing a large enough air space to ensure an adequate oxygen supply for the eggs. During incubation, the bags were periodically gently tipped back and forth to simulate crudely the stirring action that a brood fish's swimming movements might impart to its eggs. Following this, the eggs were either inseminated or left uninseminated. Insemination was accomplished using the 'dry' method $(0.3 \mathrm{ml}$ milt per 100 eggs; no water added) and was conducted while the eggs were still immersed in the clarified coelomic fluid or in the $R$, salmoninarum-contaminated coelomic fluid. Eggs were then treated at 10 to $12^{\circ} \mathrm{C}$ as follows: all lots but one were rinsed with 3 or 4 changes of sterile saline totalling 9 or 12 egg volumes, waterhardened for $2 \mathrm{~h}$ in 3 egg volumes of water or aqueous erythromycin (equivalent to $50 \mu \mathrm{g}$ of erythromycin base $\mathrm{ml}^{-1}$ ), surface-disinfected by immersion for 15 min in 3 egg volumes of 500 ppm iodine, and rinsed free of the iodine in 3 changes of sterile water totalling 9 egg volumes. The exception was treated in an identical manner except that an extra step, involving incubation for $3 \mathrm{~d}$ in flowing water, was inserted immediately following water-hardening in aqueous erythromycin phosphate. This lot was the only antibiotic-treated lot tested for its intra-ovum infection rate (Table 1, Footnote a). Eggs in the various lots were then either aseptically transferred to tubes of KDM2 broth (1 egg tube $^{-1}$ ) to permit observations on the intra-ovum infection rate (see culture method of Evelyn et al. 1984b) or were incubated in running water at 5 to $8{ }^{\circ} \mathrm{C}$ in meshbottom plastic containers ( 1 container $\operatorname{lot}^{-1}$ ), held in a Heath tray. Incubation in water permitted observations on the egg fertilization rate and on the $R$. salmoninarum infection rate in the coho fry hatching from infected eggs. The various lots of water-incubated eggs were transferred, just prior to hatching, from the Heath tray to separate $50 \mathrm{l}$ tanks to prevent cross infections among lots. The fry were reared in these tanks at
13 to $15^{\circ} \mathrm{C}$ in flowing dechlorinated city water until 97 $\mathrm{d}$ post-hatching. At this point, they were all killed with an overdose of anesthetic (2-phenoxyethanol). Kidney smears were prepared from 100 fish in each lot. These smears, along with those prepared from the few fry that died within the final $38 \mathrm{~d}$ or rearing, were examined for the presence of $R$. salmoninarum using the fluorescent antibody stain method (Bullock \& Stuckey 1975).

Identification of bacteria isolated from egg and fry samples. Bacteria isolated from egg content samples and from freshly dead fry derived from Renibacterium salmoninarum-infected eggs were shown to be $R$. salmoninarum using the morphological, serological, and nutritional criteria outlined by Evelyn et al. (1984b).

Statistical analyses. Differences in egg infection rates found for variously treated eggs were analyzed for their significance using the comparison of binomial proportions test (Kalbfleish 1976, p. 160-162). The probability that chance accounted for differences in the egg infection rates is expressed by the value of $P$.

\section{RESULTS AND DISCUSSION}

Table 2 presents the results of the egg infection trials. When eggs and milt were derived from fish free of Renibacterium salmoninarum and were not exposed in the laboratory to the pathogen, the eggs proved, as expected, to be pathogen-free whether fertilized or not. In contrast, intra-ovum infections with $R$. salmoninarum resulted in every trial in which the eggs were exposed to the higher dosage levels of $R$. salmoninarum: $1.4 \times 10^{9}$ cells $\mathrm{ml}^{-1}$ for steelhead trout eggs; $1.3 \times 10^{12}$ cells $\mathrm{ml}^{-1}$ for coho salmon eggs. The egg infection rates obtained by incubating eggs in the heavily contaminated coelomic fluid were not significantly influenced by fertilizing the eggs while they were immersed in this milieu ( $P$ values for steelhead trout and coho salmon eggs were 0.721 and 0.369 , respectively) or by water-hardening the eggs in erythromycin (P value for coho eggs was 0.109). Egg infection rates in the heavily challenged eggs were, however, significantly different from those of eggs not exposed to $R$. salmoninarum (P values for steelhead trout and coho salmon eggs were 0.004 and 0.016, respectively).

No intra-ovum infections were detected in 2 trials in which the eggs were exposed to the lower dosage levels of Renibacterium salmoninarum: $1.4 \times 10^{3}$ cells $\mathrm{ml}^{-1}$ for steelhead trout eggs; $1.3 \times 10^{6}$ cells $\mathrm{ml}^{-1}$ for coho salmon eggs. If intra-ovum infections occur at these exposure levels, they must be rare enough to require larger sample sizes for their detection.

The intra-ovum infection rates achieved using the higher dosage levels were low. They averaged 5.5 and 
Table 2. Intra-ovum infection of soft, unfertilized steelhead trout and coho salmon eggs by immersion in coelomic fluid contaminated with Renibacterium salmoninarum (Rs): effect on infection rate of Rs dosage, of fertilization in the presence of Rs, and of water-hardening eggs in aqueous erythromycin

\begin{tabular}{|c|c|c|c|c|c|c|}
\hline Egg source & $\begin{array}{c}\text { Egg } \\
\text { lot } \\
\#^{d}\end{array}$ & $\begin{array}{l}\text { Exposed to } \\
\text { indicated no. of } \\
\text { Rs cells } \mathrm{ml}^{-1}\end{array}$ & Eggs were: & $\begin{array}{l}\text { Water hardened } \\
\text { in } \\
\text { erythromycinc }\end{array}$ & $\begin{array}{l}\text { No. eggs } \\
\text { infected } \\
\text { internally } \\
\text { with Rs/no. } \\
\text { eggs tested }\end{array}$ & $\begin{array}{l}\text { Eggs (\%) } \\
\text { infected } \\
\text { internally } \\
\text { with Rs }\end{array}$ \\
\hline Steelhead trout & $\begin{array}{l}1 \\
2 \\
3 \\
4 \\
5\end{array}$ & $\begin{array}{c}0 \\
0 \\
1.4 \times 10^{3} \\
1.4 \times 10^{9} \\
1.4 \times 10^{9}\end{array}$ & $\begin{array}{l}\text { No } \\
\text { Yes } \\
\text { Yes } \\
\text { No } \\
\text { Yes }\end{array}$ & $\begin{array}{l}\text { No } \\
\text { No } \\
\text { No } \\
\text { No } \\
\text { No }\end{array}$ & $\begin{array}{l}0 / 50 \\
0 / 95 \\
0 / 96 \\
2 / 48 \\
7 / 105\end{array}$ & $\begin{array}{c}0 \\
0 \\
0 \\
4.2 \\
6.7\end{array}$ \\
\hline Coho salmon & $\begin{array}{l}1 \\
2 \\
3 \\
4 \\
5 \\
6\end{array}$ & $\begin{array}{c}0 \\
0 \\
1.3 \times 10^{6} \\
1.3 \times 10^{12} \\
1.3 \times 10^{12} \\
1.3 \times 10^{12}\end{array}$ & $\begin{array}{l}\text { No } \\
\text { Yes } \\
\text { Nn } \\
\text { No } \\
\text { Yes } \\
\text { Yes }\end{array}$ & $\begin{array}{l}\text { No } \\
\text { No } \\
\text { No } \\
\text { No } \\
\text { No } \\
\text { Yes }\end{array}$ & $\begin{array}{l}0 / 74 \\
0 / 97 \\
0 / 100 \\
4 / 100 \\
1 / 99 \\
5 / 93\end{array}$ & $\begin{array}{c}0 \\
0 \\
0 \\
4.0 \\
1.0 \\
5.4\end{array}$ \\
\hline \multicolumn{7}{|c|}{ 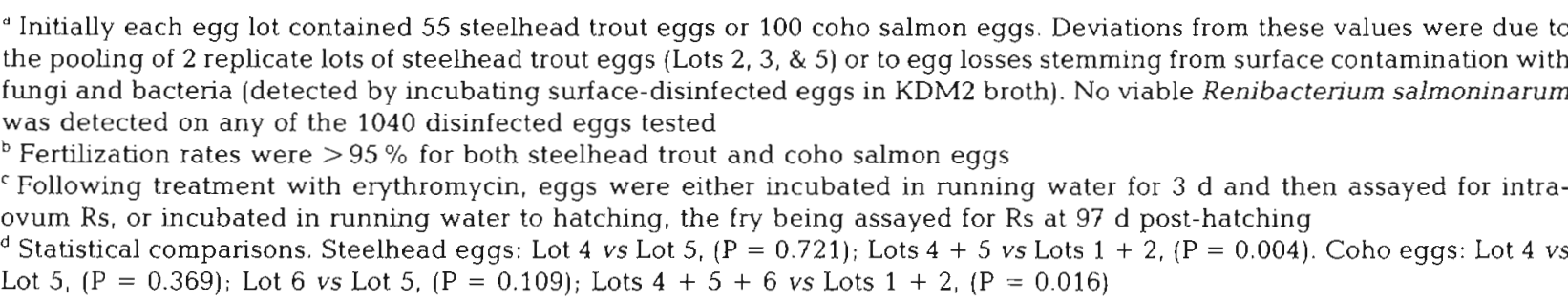 } \\
\hline
\end{tabular}

$3.5 \%$ for steelhead trout and coho salmon eggs, respectively. The infection rates were not unlike some of those observed for naturally infected eggs derived from fish in which bacterial numbers in the coelomic fluid surrounding the eggs ranged from $10^{9}$ to $10^{10}$ Renibacterium salmoninarum cells $\mathrm{ml}^{-1}$ (Evelyn et al. 1984a, b, 1986b).

Attempts to obtain high infection rates by inseminating the eggs while they were still immersed in the contaminated coelomic fluid or by using very high levels of challenge (e. g. the $10^{12}$ cells $\mathrm{ml}^{-1}$ used with the coho salmon eggs) were not successful. In the latter case, the explanation may lie in the strong tendency for Renibacterium salmoninarum cells to autoagglutinate when present in high concentrations (Evelyn et al. 1973). As a result of autoagglutination, we undoubtedly ended up very rapidly with a suspension containing a large number of cell clumps (too large to enter the egg) and a severely reduced number of single cells. As hypothesized earlier (Evelyn et al. 1984a), it is very likely that only single cells manage to enter the egg. Considering their lack of motility and the egg's ultrastructure (Stehr \& Hawkes 1979, Groot \& Alderdice 1984), they. probably do so, passively, via the micropyle.

Failure to achieve an increased infection rate by inseminating the eggs while they were still immersed in the coelomic fluid contaminated with Renibacterium salmoninarum is not understood, because we thought that the spermatozoa would have aided the entry into the egg of those $R$. salmoninarum cells lacated in the region of the micropyle. Calculations on steelhead eggs (average surface area per egg: $7.85 \times$ $10^{7} \mu^{2}$ ) show, for example, that enough $R$. salmoninarum cells (average area blanketed per cell: 0.5 $\left.\mu \mathrm{m}^{2}\right)$ were used $(1.3 \mathrm{ml}$ of a suspension containing 1.4 $\times 10^{9}$ cells $\mathrm{ml}^{-1}$ per 100 eggs) to cover potentially $20 \%$ of the egg surface. With coho eggs, the potential coverage would have been even greater $(>100 \%)$. Chances should therefore have been good that at any given instant there should have been a $R$. salmoninarum cell in a location to benefit from a spermassisted entry into the egg.

These results, obtained with fertilized eggs, suggest that the male salmonid does not play a significant role in the vertical transmission of Renibacterium salmoninarum. This conclusion is based on the view that inseminating eggs through heavily contaminated coelomic fluid is essentially the same as using $R$. salmoninarum-contaminated milt to fertilize the eggs. Other results supporting this conclusion were obtained in another experiment, only briefly mentioned here. In this experiment, which utilized steelhead trout eggs, we were again successful in obtaining egg infections 
by immersing soft eggs from $R$. salmoninarum-free broodfish in $R$. salmoninarum-contaminated coelomic fluid ( 1 of 143 eggs) or by fertilizing the eggs with uncontaminated milt while they were still immersed in the contaminated coelomic fluid (2 of 102 eggs). However, when milt, contaminated some $16 \mathrm{~h}$ before the experiment with $R$. salmoninarum, was used to fertilize the eggs, no infections were detected in 2 trials involving 138 and 148 eggs even though the concentration of contaminating cells in the milt was the same as that used in the coelomic fluid $\left(1.1 \times 10^{10}\right.$ cells $\left.\mathrm{ml}^{-1}\right)$. Infection rates in this experiment ranged from 0 to $2 \%$ and were not significantly different from each other ( $\mathrm{P}$ values ranged from 0.098 to 0.572 ). They were consistent, however, with the conclusion that the male salmonid does not play an important part in the vertical transmission of $R$. salmoninarum.

Results on the vertical transmission of Renibacterium salmoninarum with experimentally infected eggs are given in Table 3 . Coho salmon fry hatching from experimentally infected eggs proved to be infected with $R$. salmoninarum in 4 of 5 lots tested even though the eggs in 4 of the lots had been treated with erythromycin at a level 25 times that recommended by Klontz (1983) for preventing vertical transmission. In 2 of the lots (those treated with erythromycin ethylsuccinate and erythromycin base) the infections were actually lethal, and in 1 lot (treated with erythromycin base) cross infections among the fry had obviously occurred, resulting in an active outbreak of BKD and illustrating the importance of vertical transmission as a primary source of infection. The likelihood that the egg-mediated fry infections were due to $R$. salmoninarum surviving on the surface of the $R$. salmoninarum-exposed eggs is extremely remote because, as indicated in Table 2 (Footnote a), the pathogen was not detected on any of the eggs following their disinfection with povidone-iodine.

In Table 3, the failure of the fry from uninfected eggs to yield detectable Renibacterium salmoninarum was expected but a similar result in the fry resulting from the infected eggs not receiving erythromycin treatment was not. Our failure to detect vertical transmission with this group of eggs may have been due to chance. Results such as this are apparently sooner or later inevitable when studying infections that occur at low prevalence (Ossiander \& Wedemeyer 1973).

These experiments support our hypothesis that salmonid eggs acquire intra-ovum infections with Renibacterium salmoninarum from the heavily infected coelomic fluid that surrounds them in 'culprit' fish following their release to the body cavity. Whether eggs also become infected early in oogenesis is still unknown. Experiments to examine this point are underway but thus far we have succeeded only in killing fish with BKD in our attempts to answer this question.

The present experiments also prove that infected eggs can give rise to infected progeny and that the latter then provide a focus of infection that can lead to cross infections. The results support the view of Klontz (1983) that the male salmonid contributes little to the vertical transmission of Renibacterium salmoninarum but they contradict his conclusion that water-hardening eggs in erythromycin is effective in preventing vertical transmission. Data that show why erythromycin, administered during water-hardening, is ineffective for this purpose are presented elsewhere (Bullock \& Leek 1986, Evelyn et al. 1986a).

We believe that vertical transmission is of primary

Table 3. The vertical transmission of Renibacterium salmoninarum (Rs) with coho salmon eggs ${ }^{d}$ infected, intra-ovum, by immersion in Rs-contaminated coelomic fluid and treated with various forms of erythromycin $\left(50 \mu \mathrm{g} \mathrm{ml}^{-1}\right)$

\begin{tabular}{|c|c|c|c|c|}
\hline $\begin{array}{l}\text { Eggs exposed to } \\
\text { indicated no. Rs } \\
\text { cells ml } \mathrm{ml}^{-1} \\
\text { coelomic fluid }\end{array}$ & Eggs water-hardened in & $\begin{array}{l}\text { No. resulting fry } \\
\text { infected with } \\
\text { Rs } / 100 \mathrm{fry} \\
\text { tested }^{\mathrm{b}}\end{array}$ & $\begin{array}{l}\text { No. dead fry } \\
\text { with Rs/no. dead } \\
\text { fry collected }\end{array}$ & $\begin{array}{l}\text { Summary of } \\
\text { findings per } \\
\text { treatment. Fry } \\
\text { infected with Rs: }\end{array}$ \\
\hline 0 & Water & 0 & $0 / 0$ & No \\
\hline $1.3 \times 10^{12}$ & Water & 0 & $0 / 0$ & No \\
\hline $1.3 \times 10^{12}$ & Erythromycin phosphate & 2 & $0 / 2$ & Yes; covertly \\
\hline $1.3 \times 10^{12}$ & Erythromycin ethylsuccinate & 0 & $2 / 4$ & Yes; overtly \\
\hline $1.3 \times 10^{12}$ & Erythromycin stearate & 5 & $0 / 0$ & Yes; covertly \\
\hline $1.3 \times 10^{12}$ & Erythromycin base & 19 & $6 / 7$ & Yes; overtly \\
\hline \multicolumn{5}{|c|}{$\begin{array}{l}\text { a Best estimate of intra-ovum infection rate achieved in Rs-exposed eggs was } 3.5 \% \text { (average of all values for infected coho } \\
\text { salmon eggs in Table } 2 \text { ) } \\
\text { b Fry averaged } 2.04 \mathrm{~g} \text { and were sampled at } 97 \mathrm{~d} \text { post-hatching; testing for Rs was by fluorescent antibody stain method } \\
\text { " Fry died in the } 38 \mathrm{~d} \text { period prior to sampling; fry dying before this were not tested for Rs because they appeared to die of } \\
\text { starvation }\end{array}$} \\
\hline
\end{tabular}


importance in maintaining the slow-growing and fastidious Renibacterium salmoninarum in salmonid populations. In this respect, $R$. salmoninarum differs from Aeromonas salmonicida, a fish pathogenic bacterium that we have observed in coelomic fluid along with $R$. salmoninarum (Evelyn et al. $1984 \mathrm{a}$, b). We have never encountered a natural intra-ovum infection due to $A$. salmonicida, and the pathogen is generally thought to be spread horizontally rather than vertically (McCarthy \& Roberts 1980). A. salmonicida produces lethal products during growth (Munro 1984), and is well known for the acute disease, furunculosis, it causes. It can cause intra-ovum infections in the laboratory (Evelyn unpubl.) but it seems not to do so in nature, perhaps because it kills the fish before its numbers in the fish tissues are sufficiently high to ensure egg infections. That $R$. salmoninarum successfully accomplishes vertical transmission may be due largely to the fact that it does not produce particularly lethal toxins. As a result, an affected fish can survive to spawn or serve as a source of eggs for propagative purposes while carrying the enormous numbers of $R$. salmoninarum cells necessary to ensure egg infections.

Acknowledgements. We thank Dr. L. Margolis for kindly reviewing the manuscript and Dr. D. Noakes for advice and assistance with the statistical analyses.

\section{LITERATURE CITED}

Bullock, G. L., Leek, S. L. (1986). Use of erythromycin in reducing vertical transmission of bacterial kidney disease. Vet. Hum. Toxicol. 28 (Suppl. 1): 18-20

Bullock, G. L., Stuckey, H. M. (1975). Fluorescent antibody identification and detection of the Corynebacterium causing kidney disease of salmonids. J. Fish. Res. Bd. Can. 32: $2224-2227$

Evelyn, T P. T., Hoskins, G. E., Bell, G. R. (1973). First record of bacterial kidney disease in an apparently wild salmonid in British Columbia. J. Fish. Res. Bd Can. 30: $1578-1580$
Evelyn, T. P. T (1977). An improved growth medium for the kidney disease bacterium and some notes on using the medium. Bull. off. Int. Epiz. 87: 511-513

Evelyn, T P. T., Ketcheson, J. E., Prosperi-Porta, L. (1984a). Further evidence for the presence of Renibacterium salmoninarum in salmonid eggs and for the failure of povidone-iodine to reduce the intra-ovum infection rate in water-hardened eggs. J. Fish. Dis. 7: 173-182

Evelyn, T. P. T., Prosperi-Porta, L., Ketcheson J. E. (1984b). The salmonid egg as a vector of the kidney disease bacterium, Renibacterium salmoninarum. In: ACUIGRUP (ed.) Fish diseases, fourth COPRAQ session. EDITORA ATP, Madrid, Spain, p. 111-117

Evelyn, T. P. T., Ketcheson, J. E., Prosperi-Porta, L. (1986a). Use of erythromycin as a means of preventing vertical transmission of Renibacterium salmoninarum. Dis. aquat. Org. 2 in press

Evelyn, T. P. T., Prosperi-Porta, L., Ketcheson, J. E. (1986b). Persistence of the kidney discase bacterim, Renibacterium salmoninarum, in coho salmon, Oncorhynchus kisutch (Walbaum), eggs treated during and after waterhardening with povidone-iodine. J. Fish. Dis. (in press)

Groot, E. P., Alderdice, D. F. (1984). Fine structure of the external egg membrane of five species of Pacific salmon and steelhead trout. Can. J. Zool. 63: 552-566

Kalbfleish, J. G. (1976). Probability and statistical inference. University of Waterloo, Waterloo, Ontario

Klontz, G. W. (1983). Bacterial kidney disease in salmonids: An overview. In: Anderson, D. P., Dorson, M., Dubourget, P. H. (ed.) Antigens of fish pathogens. Collection Foundation Marcel Merioux, p. 177-199

McCarthy, D. H., Roberts, R. J. (1980). Furunculosis of fish the present state of our knowledge. In: Droop, M. R., Jannasch, H. W. (ed.) Advances in aquatic microbiology, Vol. 2. Academic Press Inc., New York, p. 97-120

Munro, A. L. S. (1984). A furunculosis vaccine - illusion or achievable objective. In: de Kinkelin, P. (ed.) Symposium on fish vaccination. Off. Int. Epiz., Paris, p. 97-120

Ossiander, F. J., Wedemeyer, G. (1973). Computer program for sample sizes required to determine disease incidence in fish populations. J. Fish. Res. Bd. Can. 30: 1383-1384

Stehr, C. M., Hawkes, J. W. (1979). The comparative ultrastructure of the egg membrane and associated pore structures in the starry flounder, Platichthys stellatus (Pallas) and pink salmon, Oncorhynchus gorbuscha (Walbaum) Cell Tissue Res. 202: 347-356 